\title{
Contingent Liabilities from Banks: How to Track Them?
}




\section{WP/15/255}

\section{IMF Working Paper}

\section{Contingent Liabilities from Banks: How to Track Them?}

by Serkan Arslanalp and Yin Liao

IMF Working Papers describe research in progress by the author(s) and are published to elicit comments and to encourage debate. The views expressed in IMF Working Papers are those of the author(s) and do not necessarily represent the views of the IMF, its Executive Board, or IMF management.
I $\mathrm{N}$
N T E R N A T I O N A L
$M O N E T A R Y$
F U N D 


\title{
IMF Working Paper
}

Monetary and Capital Markets Department

\section{Contingent Liabilities from Banks: How to Track Them? \\ Prepared by Serkan Arslanalp and Yin Liao ${ }^{1}$}

Authorized for distribution by Matthew Jones

December 2015

\section{IMF Working Papers describe research in progress by the author(s) and are published to elicit comments and to encourage debate. The views expressed in IMF Working Papers are those of the author(s) and do not necessarily represent the views of the IMF, its Executive Board, or IMF management.}

\begin{abstract}
In this paper, we develop a methodology to assess potential losses to the government that could arise from bank failures. The approach is intended to be simple, parsimonious, and used in real time. It generates an index that we call the banking sector contingent liability index (BCLI), based on the banking sector's size, concentration, diversification, leverage, and riskiness of assets. The index is illustrated for 32 advanced and emerging market economies from 2006 to 2013, as well as a group of banks including global systemically important banks (G-SIBs).
\end{abstract}

JEL Classification Numbers: G13,G21,G38

Keywords: Contingent Liabilities, Sovereign Risk, Banking Sector

Author's E-Mail Address: sarslanalp@,imf.org; yin.liao@qut.edu.au

\footnotetext{
${ }^{1}$ Yin Liao is affiliated with Australian National University and Queensland University of Technology. We thank Ali Abbas, Tamon Asonuma, Dale Gray, Tim Irwin, Tryggvi Gudmundsson, Andy Jobst, Will Kerry, Jean Portier, Lev Ratnovski, Luigi Ruggerone, and Miguel Savastano for helpful comments and suggestions. Di Bu provided excellent research assistance. All remaining errors are our own.
} 


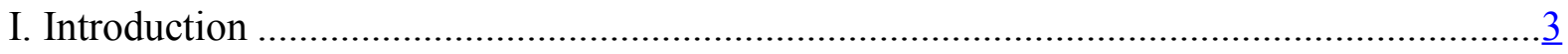

II. Contingent Liabilities, Banking Crises, and Fiscal Costs …………...................................

III. A Model of Contingent Liabilities ...............................................................................

A. Contingent Liability Related to a Single Bank ………………………………….... 6

B. Contingent Liability Related to the Banking Sector ..................................................

C. Contingent Liability when Bank Distress is Correlated........................................... 8

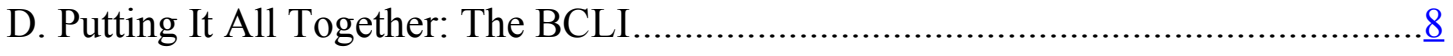

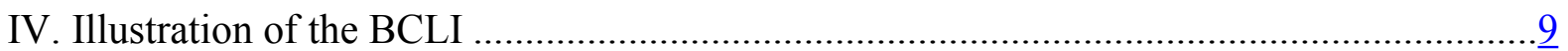

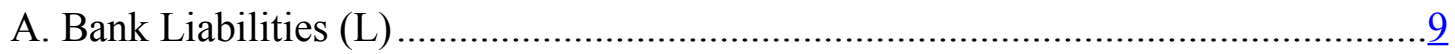

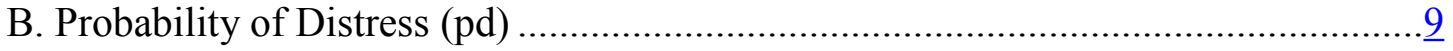

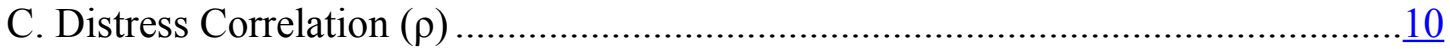

D. Probability of State Support Given Distress (pss) ……………………………...10

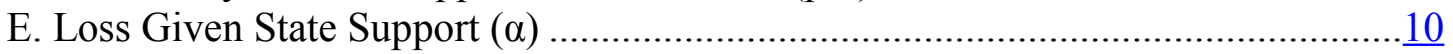

F. Country Estimates.....................................................................................

G. Bank-by-Bank Estimates.............................................................................16

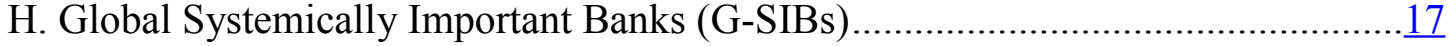

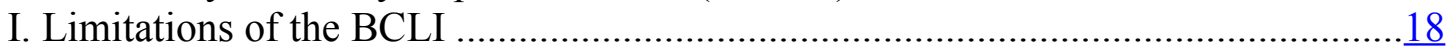

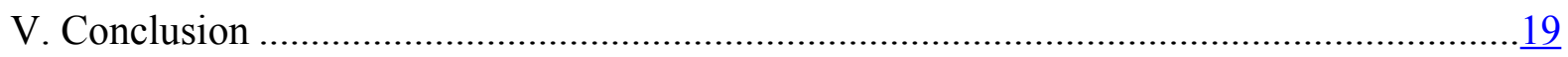

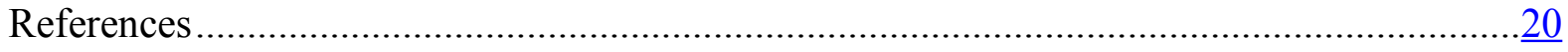

Tables

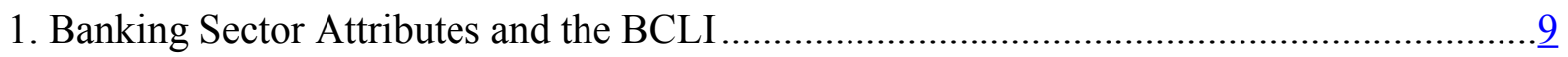

Figures

1. Banking Sector Contingent Liability Index (BCLI), 2006-13 ………...........................12

2. Advanced Economies: Components of the BCLI, 2006-13 ..........................................13

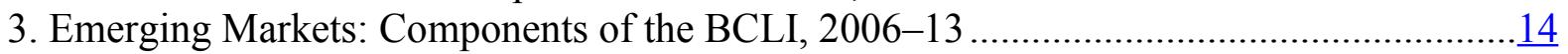

4. Fiscal Costs of Bank Support Measures, 2007-11 ……................................................15

5. Banking Sector Contingent Liability Index (BCLI) for Australia, 2006-13 ……...............16

6. Banking Sector Contingent Liability Index (BCLI) for G-SIBs, 2006-13 .........................17

Appendixes

1. Moody's Measure of Expected Default Frequency (EDF) ………………………..........23

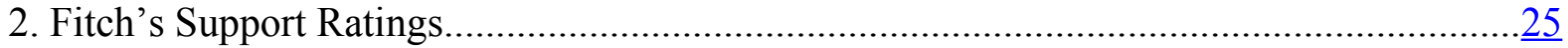

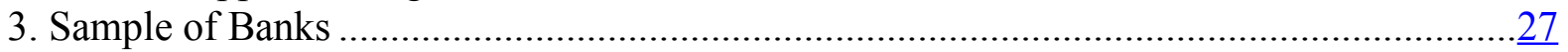




\section{INTRODUCTION}

History suggests that banking crises are often followed by sovereign debt crises (Reinhart and Rogoff, 2009). Most recently, the global financial crisis and the euro area debt crisis have highlighted that banking sector problems in a country can lead to large sovereign debt problems. For instance, the gross fiscal cost of supporting troubled banks in Iceland and Ireland exceeded 40 percent of GDP, well above the standard 10 percent of GDP contingent liability shock assumed in public debt sustainability analyses.

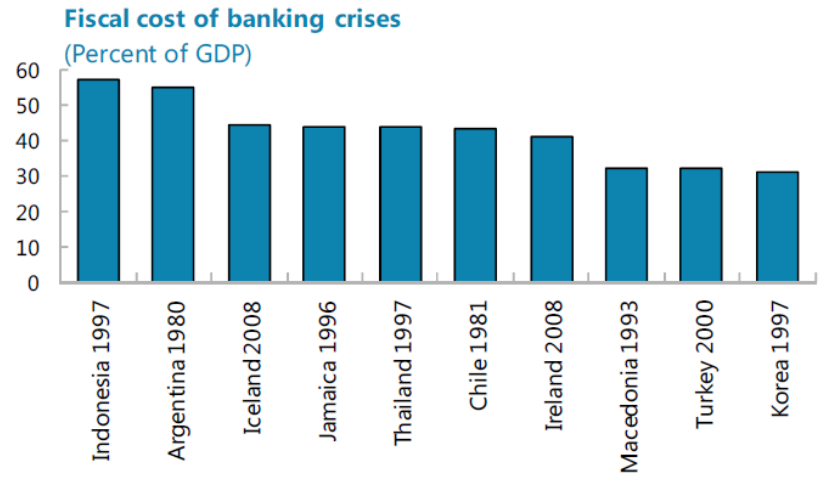

Source: Laeven and Valencia, "Systemic Banking Crises Database: an Update", 2012.

To the extent that banking problems generate fiscal costs, a bank can be seen as a contingent liability for the government. The problem with contingent liabilities, however, is that they are recognized only after they materialize. What is needed is a way to track how these contingent liabilities are changing, whether they materialize or not. That would give a better sense of the risks that may transmit to the government's balance sheet, if and when a bank falls under stress and the government has to step in to support it.

In a recent paper (Arslanalp and Liao, 2014), we showed that an index designed to track bank-related contingent liabilities could explain part of the variation in sovereign credit default swap spreads for a panel of countries from 2006 to 2013. In this paper, we provide the final version of this index, along with a step by step explanation of how it can be calculated for a group of major advanced and emerging market economies. In doing so, we hope others can replicate the index and use it for their own purposes.

Towards that goal, the first part of the paper develops a methodology to assess potential losses to the government that could arise from bank failures. In particular, the approach treats the liabilities of each bank as having an implicit guarantee from the government and the liabilities of the banking sector as a portfolio of guarantees. ${ }^{2}$ The expected and unexpected costs of the guarantees can then be calculated, based on the likelihood of government support. We show that these costs are a function of the size, concentration, diversification, leverage, and asset riskiness of the banking sector.

The expected and unexpected costs are then summarized in an index that we call the banking sector contingent liability index (BCLI). The BCLI is an index of the fiscal risks that could be created by banks (in percent of GDP) under an adverse scenario defined as a two-standard deviation event. When the banking sector is diversified and has many banks, the BCLI can be interpreted as the government's "value-at-risk" at the 5 percent likelihood level.

\footnotetext{
${ }^{2}$ Similar approaches have been used by the FDIC (2003) in assessing the adequacy of deposit insurance funds, and by Irvin (2007) in valuing government guarantees related to infrastructure projects.
} 
The second part of the paper shows how the BCLI can be constructed for 32 advanced and emerging market economies on a monthly basis. It illustrates its use for individual countries and groups of banks. It also shows that countries with relatively high BCLIs were more likely to experience larger fiscal costs during and after the global financial crisis.

The paper is organized as follows. Section II provides some background on past banking crises and fiscal costs. Section III describes the construction of the BCLI. Section IV illustrates the BCLI for 32 advanced and emerging market economies. Section V concludes.

\section{Contingent Liabilities, Banking Crises, ANd Fiscal Costs}

Contingent liabilities are obligations entered into by government commitments, which can materialize based on the occurrence of an uncertain future event (IMF, 2001). Depending on the commitment, contingent liabilities can be either explicit or implicit. Explicit liabilities are created by a law or contract, while implicit liabilities are obligations of the government that reflect public interest or special-interest group pressures (Cebotari, 2008).

Among all contingent liabilities, those related to bank failures constitute one of the most important sources of fiscal risk for governments. Contingent liabilities related to banks include both explicit guarantees, such as deposit insurance programs, and implicit guarantees, such as guarantees on bank debt that may be provided during a banking crisis.

Fiscal costs related to bank bailouts often arise from such guarantees, as they become necessary to limit contagion and loss of confidence in the banking system (Claessens and Klingebiel, 2002). For instance, during the global financial crisis, the European Union (EU) countries approved guarantees on bank liabilities totaling 30 percent of 2011 EU GDP from the first quarter of 2008 to the third quarter of 2012, with Ireland providing guarantees of about 250 percent of 2011 GDP (Correa and Sapriza, 2014). Similarly, in 2008, the U.S. authorities adopted the Debt Guarantee Program that guaranteed newly issued senior debt of banks, providing debt guarantees in excess of $\$ 600$ billion.

When the government decides to backstop the banking sector, fiscal costs often arise, either in the form of bank recapitalization or bank resolutions costs (depending on whether the bank remains viable or not). International experience based on banking crises in 70 countries from 1970 to 2011 suggests that, fiscal costs, on average, have been in the order of 12 percent of GDP, while for the top ten percentile the cost has been more than 30 percent of GDP (Laeven and Valencia, 2013). Costs were higher especially when the banking crisis was accompanied by a currency crash (Hoggarth, Reis, Saporta, 2002). In turn, banking crises were often followed by sovereign debt crises (Reinhart and Rogoff, 2009).

Given that a country's banking sector can create significant fiscal risks, it is important to produce estimates of the value of bank-related contingent liabilities. A recent OECD survey (Schich and Aydin, 2014) highlights that country authorities have not settled on the best way of measuring such liabilities. Towards that goal, the next section develops a measure that is intended to be simple, parsimonious, and used in real time. 


\section{A Model of Contingent Liabilities}

In this section, we develop a methodology to assess potential losses to the government that could arise from bank failures. In particular, the approach treats the liabilities of each bank as an implicit guarantee of the government and liabilities of the banking sector as a portfolio of guarantees. The guarantees are implicit because they are triggered only in the event that a bank falls into distress and the government is willing and able to support the bank.

The expected and unexpected costs of the guarantees can then be calculated, based on a standard portfolio credit risk approach. The expected cost reflects the average cost of the guarantee being called, while the unexpected cost represents the volatility, or standard deviation of potential losses to the government. We consider both costs, as looking only at the expected cost would miss the range of losses associated with the contingent liability. ${ }^{3}$ These costs are determined by the size, concentration, diversification, leverage, and asset riskiness of the banking sector.

We proceed in four steps. First, we show how to calculate the expected and unexpected cost of an implicit guarantee provided to a single bank (Section III.A). Second, we show the same calculation for a portfolio of guarantees provided to the entire banking sector with $\mathrm{N}$ banks, where each bank failure is an independent event (Section III.B). Third, we show how the previous calculation would change when we allow for correlated bank failures (Section III. C). In the final step, we show how these calculations can be summarized in an index that we call the Banking Sector Contingent Liability Index (BCLI).

\footnotetext{
${ }^{3}$ In fact, in most cases, we find that empirically the unexpected costs are much higher than the expected costs.
} 


\section{A. Contingent Liability Related to a Single Bank}

We define a government's contingent liability related to a bank failure as follows:

$$
c l_{i t}= \begin{cases}0 & \text { with prob }\left(1-p d_{i t}\right) \\ 0 & \text { with prob pdit }\left(1-d_{i t}\right) \\ \alpha l_{i t} & \text { with prob pdit }{ } s s_{i t}\end{cases}
$$

Where:

$l_{i t}$ represents the total non-equity liabilities of bank $i$ at time $t$, in percent of GDP.

$p d_{i t}$ is the probability that bank i falls into distress at time t. As will be explained later, this will be a function of the leverage and asset riskiness (i.e. volatility) of the bank.

pss $_{i t}$ is the probability of state support to bank $\mathrm{i}$, conditional on the bank falling into distress.

$\alpha$ is the average loss given government support per dollar of bank liability. The losses reflect either resolution or recapitalization costs, as the bank writes down its assets to market value.

The expected cost of this implicit public guarantee can then be calculated as follows:

$$
e l_{i t}=E\left(c l_{i t}\right)=\alpha l_{i t} p d_{i t} p s s_{i t}
$$

Similarly, the unexpected cost of the guarantee (as measured by the standard deviation of potential losses) can be calculated as follows: ${ }^{4}$

$$
\begin{aligned}
v l_{i t}=\operatorname{Var}\left(c l_{i t}\right)=E\left[\left(c l_{i t}-e l_{i t}\right)^{2}\right] & =\alpha^{2} l_{i t}^{2} p d_{i t} p s s_{i t}\left(1-p d_{i t} p s s_{i t}\right) \\
u l_{i t} & =\sqrt{v l_{i t}}
\end{aligned}
$$

\section{B. Contingent Liability Related to the Banking Sector}

Suppose now there are $\mathrm{N}$ banks in the banking system. The government's contingent liability related to the whole banking system can then be expressed as follows:

$$
C L_{t}=\sum_{i=1}^{N} c l_{i t}
$$

\footnotetext{
${ }^{4}$ A low standard deviation would indicate that the cost of the guarantee would tend to be close to the mean (and hence the unexpected costs would be low), while a high standard deviation would indicate larger losses.
} 
For the time being, suppose that the likelihood of a bank falling into distress is independent of other banks falling into distress (i.e., $c l_{i t}$ are independent draws). In that case, the expected cost of the contingent liability $\left(E L_{t}\right)$ can be expressed as follows:

$$
\begin{gathered}
E L_{t}=E\left(C L_{t}\right)=E\left(\sum_{i=1}^{N} c l_{i t}\right)=\sum_{i=1}^{N} E\left(c l_{i t}\right)=\sum_{i=1}^{N} e l_{i t} \\
E L_{t}=\alpha \sum_{i=1}^{N} l_{i t} p d_{i t} p s s_{i t}
\end{gathered}
$$

Similarly, the unexpected cost $\left(U L_{i t}\right)$ can be calculated as follows:

$$
\begin{gathered}
V L_{t}=\operatorname{Var}\left(C L_{t}\right)=\operatorname{Var}\left(\sum_{i=1}^{N} c l_{i t}\right)=\sum_{i=1}^{N} \operatorname{Var}\left(c l_{i t}\right)=\sum_{i=1}^{N} v l_{i t} \\
V L_{t}=\alpha^{2} \sum_{i=1}^{N} l_{i t}^{2} p d_{i t} p s s_{i t}\left(1-p d_{i t} p s s_{i t}\right) \\
U L_{t}=\sqrt{V L_{t}}
\end{gathered}
$$

For a non-concentrated banking system, where all banks are of identical size $\left(L_{t} / N\right)$, equations 6 and 8 can be simplified to:

$$
\begin{gathered}
E L_{t}=\alpha \frac{L_{t}}{N} \sum_{i=1}^{N} p d_{i t} p s s_{i t} \\
U L_{t}=\alpha \frac{L_{t}}{N} \sqrt{\sum_{i=1}^{N} p d_{i t} p s s_{i t}\left(1-p d_{i t} p s s_{i t}\right)}
\end{gathered}
$$

Moreover, if banks have identical probabilities of distress and state support, equations 9 and 10 further simplify to:

$$
\begin{gathered}
E L_{t}=\alpha L_{t} p d_{t} p s s_{t} \\
U L_{t}=\alpha \frac{L_{t}}{\sqrt{N}} \sqrt{p d_{t} p s s_{t}\left(1-p d_{t} p s s_{t}\right)}
\end{gathered}
$$

Importantly, the last two equations show that when a banking system becomes less concentrated $(\mathrm{N} \uparrow)$, the unexpected cost (UL) of the public guarantee declines at a pace determined by the number of banks (by $\sqrt{N}$ specifically), while the expected cost (EL) remains unchanged. 


\section{Contingent Liability when Bank Distress is Correlated}

Let us now lift the assumption of uncorrelated bank failures. Suppose now that banks are more likely to fail at the same time either because they have balance sheet linkages, common exposures, or similar business models. In that case, $c l_{i t}$ and $c l_{j t}$ are no longer independent draws, but dependent variables with a correlation coefficient of, say, $\rho_{\mathrm{ij} \mathrm{t}}$.

The possibility of joint bank failures does not change the expected cost (EL) of the guarantee, but alters the unexpected cost (UL). ${ }^{5}$ In particular, equation 6 remains valid, but equation 7 needs to be modified as follows:

$$
\begin{aligned}
& V L_{t}=\operatorname{Var}\left(\sum_{i=1}^{N} c l_{i t}\right)=\sum_{i=1}^{N} \sum_{j=1}^{N} \operatorname{Covar}\left(c l_{i t}, c l_{j t}\right) \\
& V L_{t}=\alpha^{2}\left[\begin{array}{lll}
l_{1 t} & \cdots & l_{N t}
\end{array}\right]\left[\begin{array}{ccc}
p_{11 t} & \cdots & p_{1 N t} \\
\vdots & \ddots & \vdots \\
p_{1 N t} & \cdots & p_{N N t}
\end{array}\right]\left[\begin{array}{c}
l_{1 t} \\
\vdots \\
l_{N t}
\end{array}\right] \\
& p_{\mathrm{ij} t}=\rho_{\mathrm{ijt}} \sqrt{p d_{i t} p s s_{i t}\left(1-p d_{i t} p s s_{i t}\right) p d_{j t} p s s_{j t}\left(1-p d_{j t} p s s_{j t}\right)}
\end{aligned}
$$

Note that when $c l_{i t}$ and $c l_{j t}$ are uncorrelated (i.e., when $\rho_{\mathrm{ij}} \mathrm{t}=0$ for $\mathrm{i} \neq \mathrm{j}$ ), equation 13.2 simplifies back to equation 7.2.

\section{Putting It All Together: The BCLI}

Putting this all together, we define an index that we call the Banking Sector Contingent Liability Index (BCLI) as follows:

$$
B C L I_{t}=\left(E L_{t}+2 U L_{t}\right)
$$

The index is defined this way for three reasons. First, the definition captures both the expected cost (EL) and the unexpected cost (UL) of the public guarantee, expressed in percent of GDP. Second, the definition allows an interpretation of the BCLI as an estimate of losses that may arise under an adverse scenario characterized as a two-standard deviation event, a useful metric in risk management. Third, when the banking sector is diversified and has many banks (i.e., when $\rho$ is close to zero and $\mathrm{N}$ is large), the probability distribution of the contingent liability (CL) would start to resemble a normal distribution; in that case the BCLI can be interpreted as the government's "value-at-risk" at the 5 percent likelihood level.

\footnotetext{
${ }^{5}$ This is simply because, when $A$ and $B$ are correlated events, $E(A+B)$ is still equal to $E(A)+E(B)$, but $V$ ar $(\mathrm{A}+\mathrm{B})$ is equal to $\operatorname{Var}(\mathrm{A})+\operatorname{Var}(\mathrm{B})+\operatorname{Covar}(\mathbf{A}, \mathbf{B})$.
} 
Moreover, the BCLI, as defined above, would capture some of the key attributes of a banking sector. In particular, it would tend to rise, as the banking sector becomes larger (L $\uparrow)$, more concentrated $(\mathrm{N} \downarrow)$, less diversified $(\rho \uparrow)$, or more risky $(\mathrm{pd} \uparrow)$ either because of higher leverage or higher asset volatility (Table 1$)$.

Table 1. Banking Sector Attributes and the BCLI

\begin{tabular}{|c|c|c|c|c|}
\hline Attribute & Parameter & $\begin{array}{l}\text { Expected Cost } \\
\text { of Guarantee }\end{array}$ & $\begin{array}{c}\text { Unexpected Cost } \\
\text { of Guarantee }\end{array}$ & BCLI \\
\hline Size $\uparrow$ & $\mathrm{L} \uparrow$ & $\uparrow$ & $\uparrow$ & $\uparrow$ \\
\hline Concentration $\uparrow$ & $\mathrm{N} \downarrow$ & No change & $\uparrow$ & $\uparrow$ \\
\hline Diversification $\uparrow$ & $\rho \downarrow$ & No change & $\downarrow$ & $\downarrow$ \\
\hline Bank leverage $\uparrow$ & $\mathrm{pd} \uparrow$ & $\uparrow$ & $\uparrow$ & $\uparrow$ \\
\hline Bank asset volatility $\uparrow$ & $\operatorname{pd} \uparrow$ & $\uparrow$ & $\uparrow$ & $\uparrow$ \\
\hline
\end{tabular}

Note: $\mathrm{L}=$ banking sector size; $\mathrm{N}=$ number of banks in the system; $\rho=$ distress correlation among banks; $\mathrm{pd}=$ probability of bank distress.

\section{ILLUSTRATION OF THE BCLI}

An illustration of the BCLI using a particular set of data series as proxies for the variables in equation 14 is provided below.

\section{A. Bank Liabilities (L)}

For L, we use the "total adjusted liabilities" measure of bank liabilities, calculated by Moody's based on reported financial statements. These capture all bank liabilities, except equity, minority interest, and deferred taxes. It is a broad measure of bank liabilities that may receive protection under a government bailout, either due to explicit or implicit guarantees.

\section{B. Probability of Distress (pd)}

For pd, we use a probability of distress measure derived from equity markets, provided by Moody's - the Expected Default Frequency (EDF). Moody's EDF risk measure is one of the most widely used default probability metrics for corporates and financial institutions. It is an equity-market implied probability of distress based on the leverage and asset volatility of a firm. Because it is based on equity prices, it is available for a large sample of banks on a regular (most often daily) basis. ${ }^{6}$ In all cases, we use the EDF over a 1 year horizon. Appendix 1 provides further details on the construction of the EDF, including how it differs from other equity-market implied models such as Merton (1974) that assume a normal distribution, as well as other measures based on bond or credit default swap (CDS) spreads.

\footnotetext{
${ }^{6}$ For almost all banks in the sample, Moody's provides the standard EDF measure. For 22 banks that do not have publicly listed equity — notably some regional banks in Germany and Spain — we use the CDS-implied EDF measure from Moody’s. These banks are shown in italics in Appendix Table 2.
} 


\section{Distress Correlation ( $\rho)$}

For $\rho$, we use a 12-month rolling window correlation of pair-wise EDFs. The more similar the business models of banks are, the higher should be the correlation of their EDFs, and the likelihood of falling into distress at the same time.

\section{Probability of State Support Given Distress (pss)}

For pss, we use the Fitch Support Ratings, following IMF (2014) and Ueda and Weder di Mauro (2013). In particular, we rely on the Support Ratings (SRF) and Support Rating Floors (SRFs) that Fitch provides for each rated bank, which together reflect the rating agency's view on the ability and propensity of the sovereign to provide support to the bank in the event of distress. When a bank does not have an assigned support rating, we use the average support rating for other banks in the bank's home country.

\section{E. Loss Given State Support ( $\alpha)$}

For $\alpha$, we use a relatively conservative assumption of 20 percent loss per insured liability. The assumption is informed by findings of Laeven and Valencia $(2010,2013)$ who show that the gross fiscal cost of bank bailouts have historically been in the order of 20 percent of bank assets for emerging and developing economies (although somewhat less for advanced economies). ${ }^{7}$ It is also motivated by the fact that during periods of widespread bank failures, it is often difficult to sell assets of failed banks at attractive prices because other banks are also experiencing financial constraints (Shleifer and Vishny 1992; Allen and Gale 1994).

\section{F. Country Estimates}

Using the data sources listed above, we construct the BCLI for 258 banks in 32 countries. The banks are selected to capture at least half — and usually more than 80 percent — of the national banking system in each country (i.e. excluding foreign subsidiaries), as expressed in terms of total assets.

The sample includes all global systemically important banks (G-SIBs) as of November 2014, except for ING Bank. For the U.S., the sample includes all banks that participated in the 2011-13 stress testing exercise under the Comprehensive Capital Analysis and Review (CCAR), with the exception of Ally Financial (previously General Motors Acceptance Corporation, or GMAC). The countries in the sample include 23 of the 29 jurisdictions that are deemed to have systemically important financial sectors by the IMF as of end-2014. ${ }^{8}$

\footnotetext{
${ }^{7}$ In the latest banking crisis in Ireland, for example, the gross fiscal cost of public support measures (40 percent of GDP) amounted to16 percent of insured bank liabilities (250 percent of GDP). In the U.S., for which data on bank failures are available since the 1930s, the median loss rate in bank failures has been about 20 percent of the assets of failed banks (see Figure 8 in Laeven and Valencia, 2010).

${ }^{8}$ These jurisdictions are Australia, Austria, Belgium, Brazil, Canada, China, Denmark, Finland, France, Germany, Hong Kong SAR, India, Ireland, Italy, Japan, Korea, Luxembourg, Mexico, Netherlands, Norway, Poland, Russia, Singapore, Spain, Sweden, Switzerland, Turkey, the United Kingdom, and the United States. More information on the list can be found at http://www.imf.org/external/np/sec/pr/2014/pr1408.htm
} 
Overall, for advanced economies, the sample covers 148 banks with total consolidated assets of around $\$ 65$ trillion, as of end-2014. For emerging markets, it covers 110 banks with total assets of around \$20 trillion as of end-2014. Appendix 3 provides the full list of banks in the sample. Figure 1 presents the calculated BCLI for all countries in the sample divided in six groups from 2006 to 2013.

A general trend across all countries is the rise in bank-related contingent liabilities during the global financial crisis of 2008-09. In the index, there is also a noticeable second rise during the euro zone crisis of 2011-12, though this rise is more clearly noted in European countries (Figure 1).

Among major advanced economies, the rise in the BCLI following the global financial crisis was most pronounced in Germany, France, and the U.K. (Figure 1). In these countries, the BCLI remained elevated as of end-2013, compared to pre-crisis levels, as a result of total bank liabilities remaining high, and perceived probabilities of state support being on the whole higher (Figure 2). In contrast, in the U.S., and to a large extent in Japan, the BCLI returned to pre-crisis levels.

Among other euro area countries, the rise in the BCLI was most pronounced in Ireland at the time of the global financial crisis, and in Greece, Portugal, as well as in Austria, Italy, and Spain during 2011-12. In all these countries, the BCLI declined substantially following the euro zone crisis of 2011-12, but remains elevated compared to pre-crisis levels, as total bank liabilities remain above pre-crisis levels with the exception of Ireland, and probabilities of bank distress still remain relatively high in some cases (Figure 2). At the same time, the likelihood of state support is assessed to be lower now, partly driven by the reduced sovereign debt ratings in these countries which affect the government's ability to support the banking system (Figure 2$)^{9}$

Among other European countries, the rise in the BCLI was the largest in Switzerland, followed by Denmark and Sweden (Figure 1). Like euro area countries, contingent liabilities have declined substantially in these countries after the euro zone crisis of 2011-12, but still remain elevated compared to pre-crisis levels, despite the fact that total bank liabilities have declined significantly in Switzerland (Figure 2).

Among other advanced economies, the rise in the BCLI was most pronounced in Singapore, while it remains elevated in Australia, Canada, and Korea (Figure 1); this is so because total bank liabilities have risen (especially in Singapore), and the likelihood of state support to large banks, as assessed by Fitch, remains high (Figure 2).

\footnotetext{
${ }^{9}$ The rollout of a formal EU resolution framework (BRRD) and the experience of the resolution of the Cypriot banking sector in 2013 may have also lowered the assessed likelihood of state support.
} 
Figure 1. Banking Sector Contingent Liability Index (BCLI), 2006-13 (Percent of GDP)

Major Advanced Economies

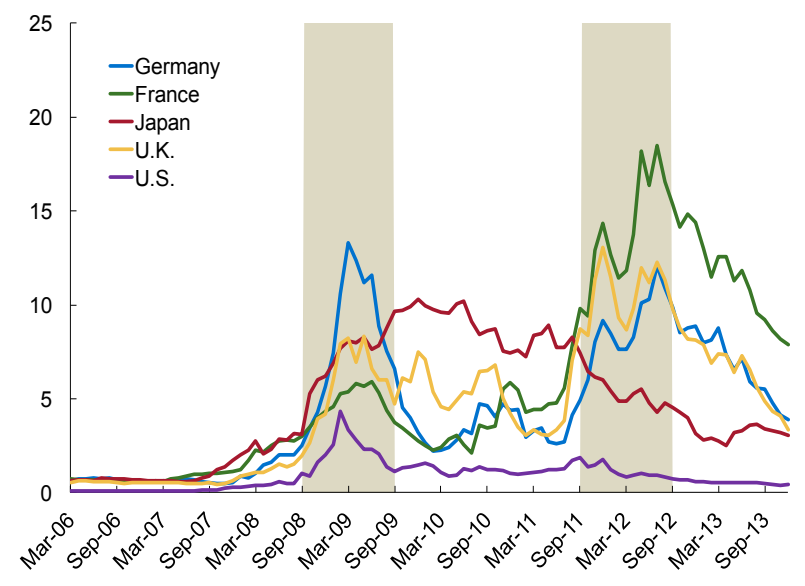

Other European Countries

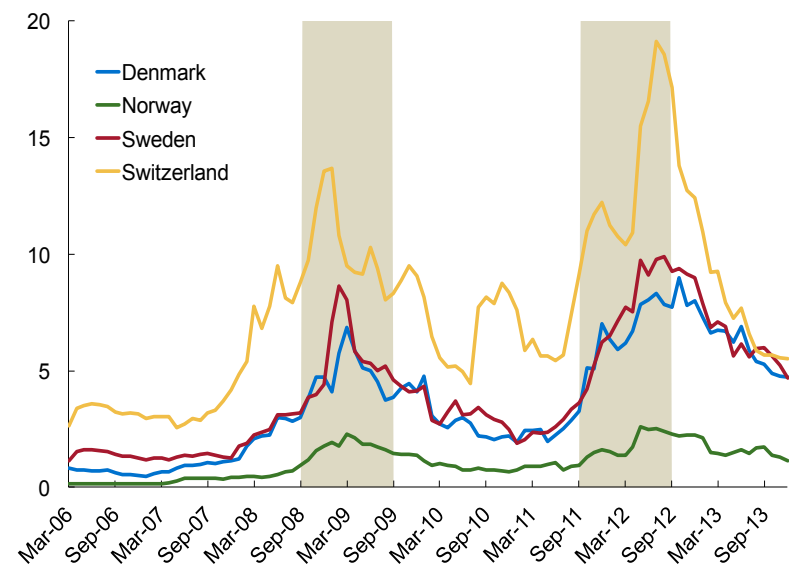

Major Emerging Markets

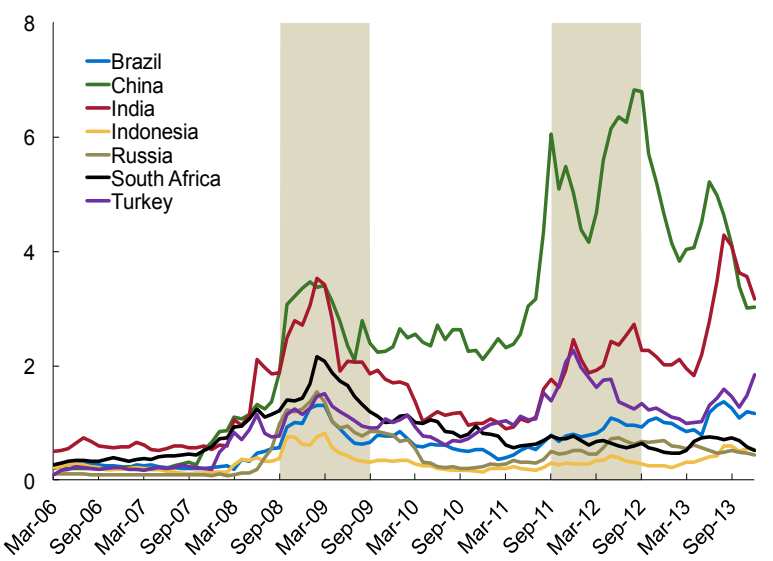

Other Euro Area Countries

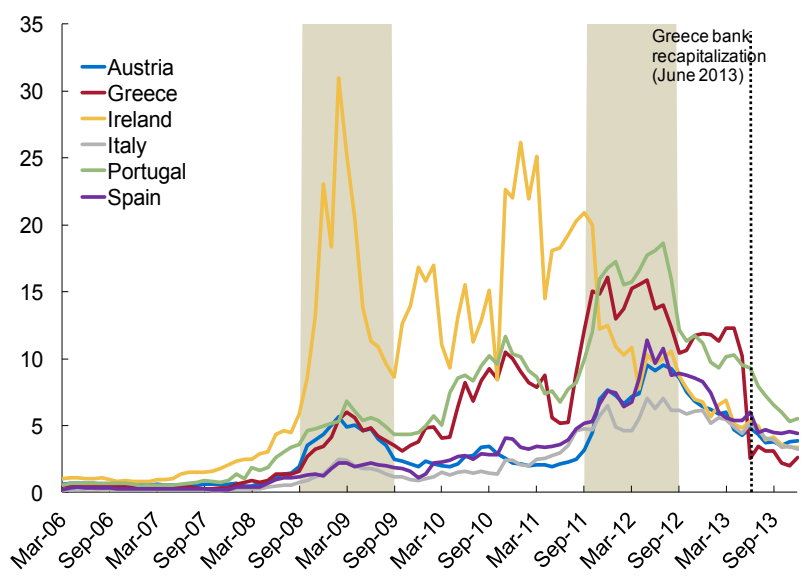

Other Advanced Economies

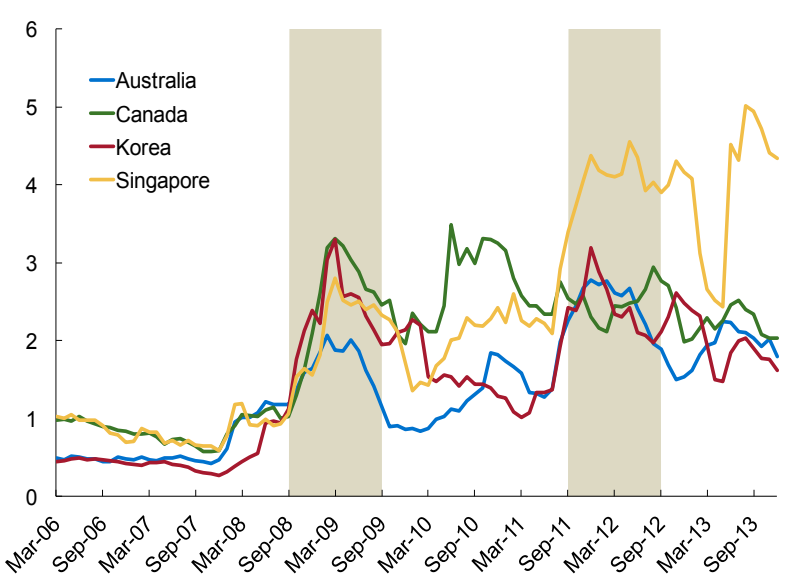

Other Emerging Markets

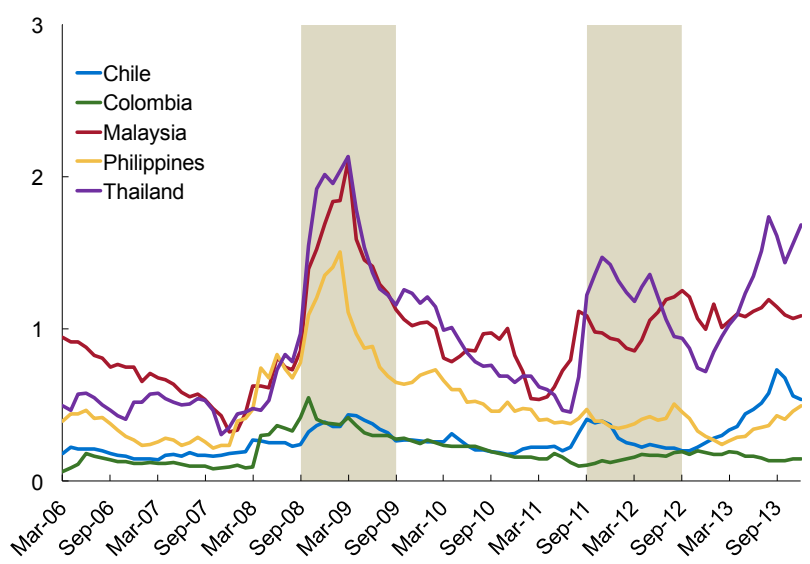

Source: Authors' calculations.

Note: The shaded areas represent the global financial crisis of 2008-09 and the euro area debt crisis of 2011-12. 
Figure 2. Advanced Economies: Components of the BCLI, 2006-13

Total Adjusted Liabilities

(Percent of GDP)

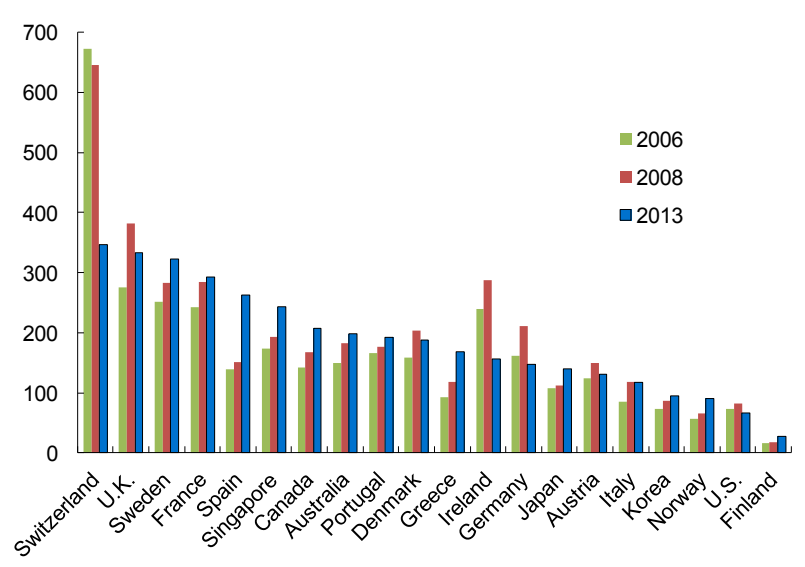

Correlation of Expected Default Frequencies

(Percent)

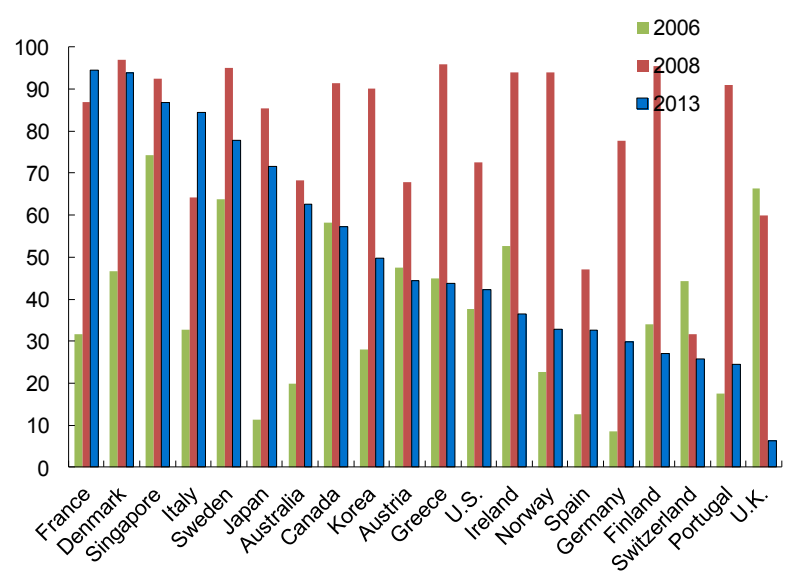

1-Year Expected Default Frequencies

(Percent)

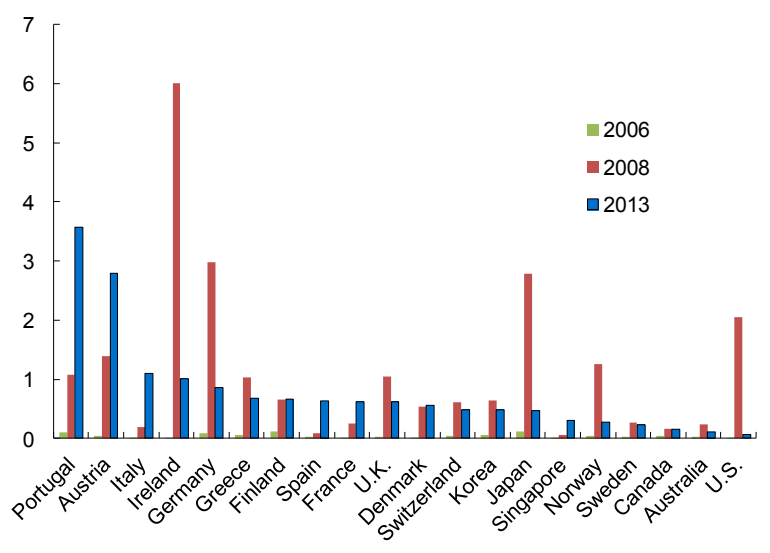

Probability of State Support

(Percent)

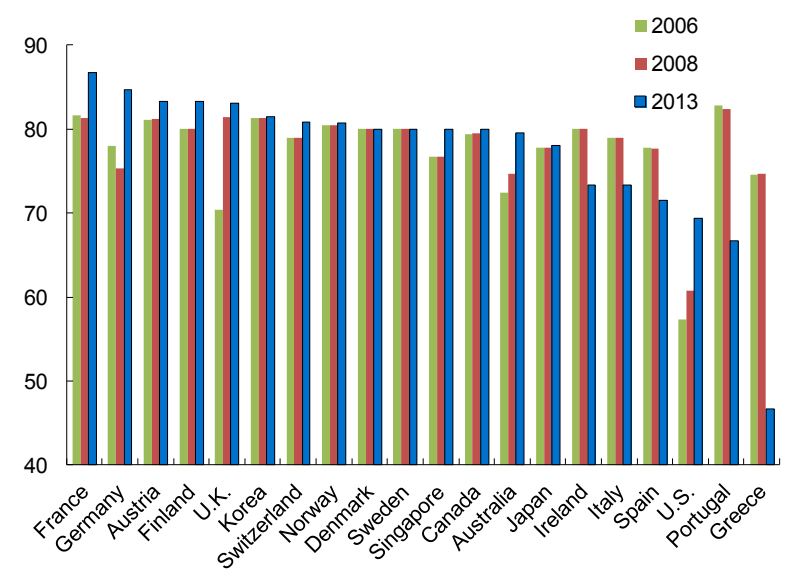

Source: Authors' calculations.

Note: Figures for country groups reflect weighted averages based on banks' total adjusted liabilities.

Among major emerging market economies, the rise in the BCLI was most pronounced in China and more recently India; it also rose in Brazil and Turkey but from relatively low levels (Figure 1). The behavior of the BCLI in China was driven by rising total bank liabilities, elevated probabilities of bank distress, and high perceived likelihood of state support (Figure 3), given government ownership of the banking system is high.

Among other emerging market economies, the rise in the BCLI was most pronounced in Malaysia and Thailand, but remained relatively low for Chile and Colombia (Figure 1), reflecting the generally smaller banking systems and lower bank distress probabilities in those countries (Figure 3). 
Figure 3. Emerging Markets: Components of the BCLI, 2006-13

Total Adjusted Liabilities

(Percent of GDP)

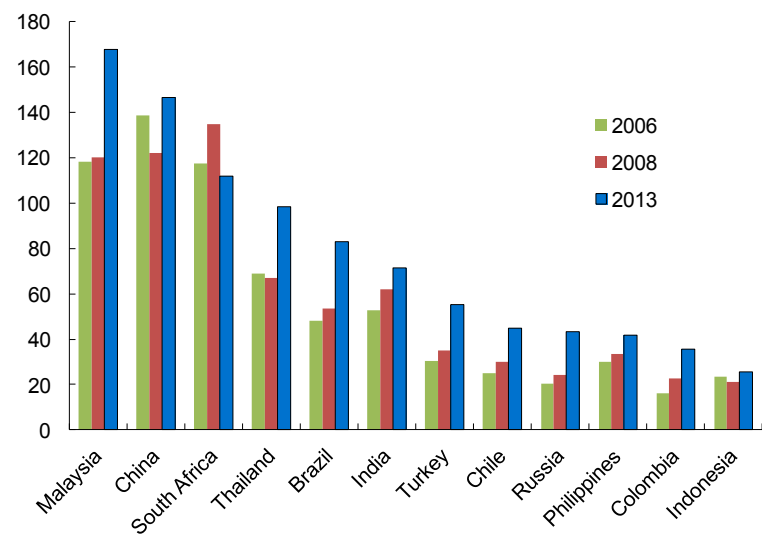

Correlation of Expected Default Frequencies (Percent)

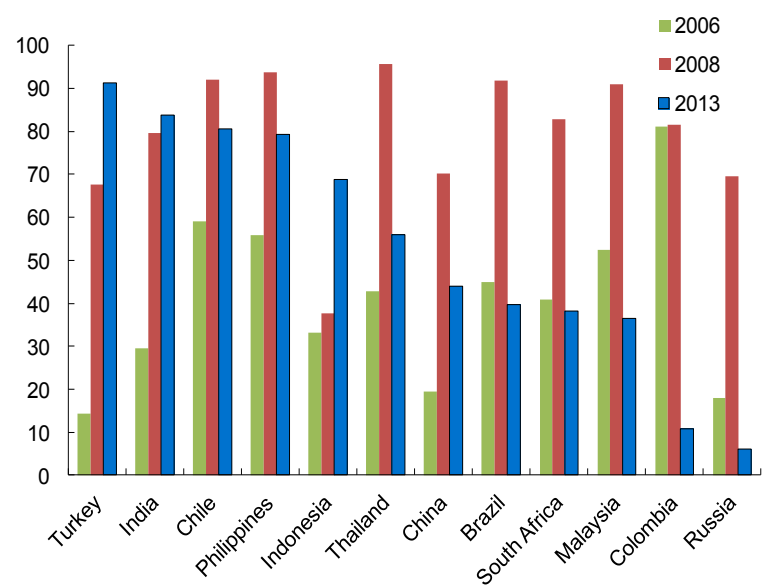

1-Year Expected Default Frequencies

(Percent)
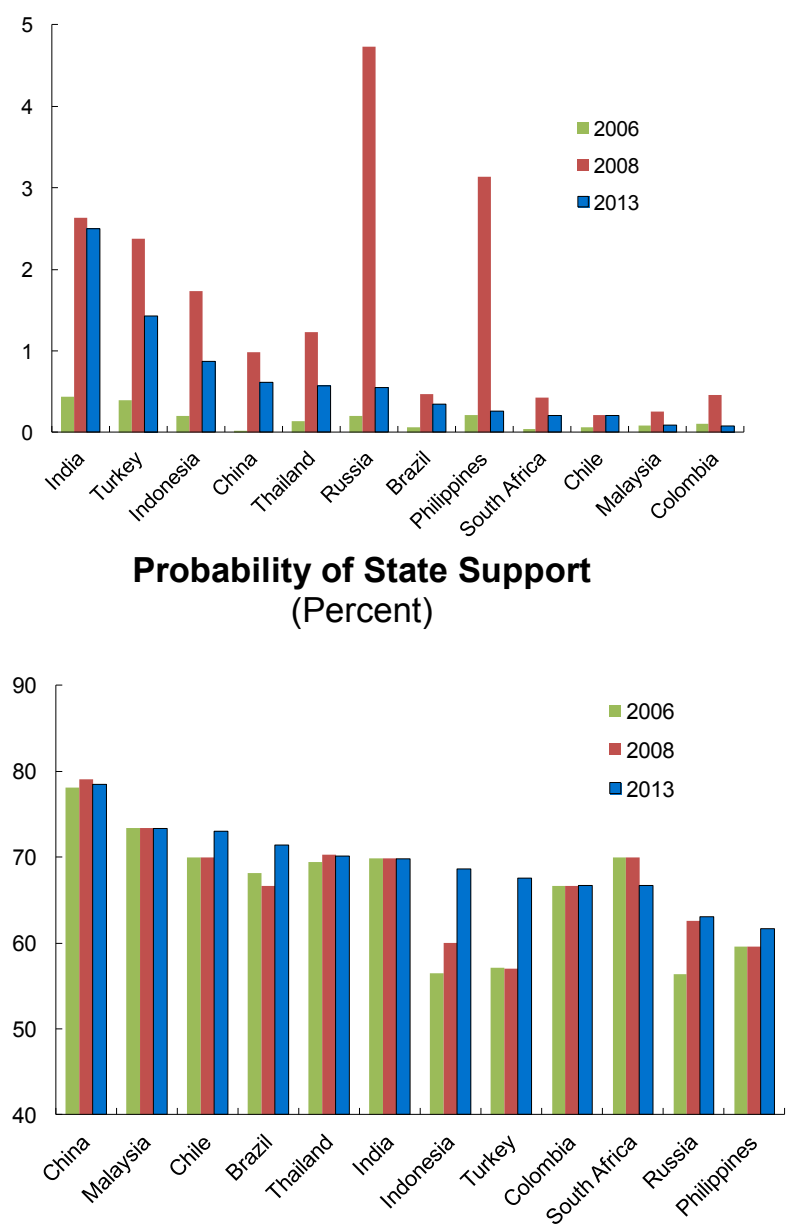

Source: Authors' calculations.

Note: Figures for country groups reflect weighted averages based on banks' total adjusted liabilities. 
Finally, we show that countries with relatively high BCLIs indeed experienced larger fiscal costs due to bank support measures following the global financial crisis. Figure 4 shows the largest fiscal costs associated with bank support measures during 2007-2011 for our sample of countries. These come from a comprehensive database on systemic banking crises that includes information up to 2011 (Laeven and Valencia, 2013). Among the eight countries that experienced the largest fiscal costs include six of the countries identified by the BCLI as having relatively high contingent liability risk. The large overlap between the two groups suggests that the BCLI would have been a useful indicator to identify and rank order countries in terms of their contingent liability risk during the global financial crisis. ${ }^{10}$

Figure 4. Fiscal Costs of Bank Support Measures, 2007-11

(Percent of GDP)

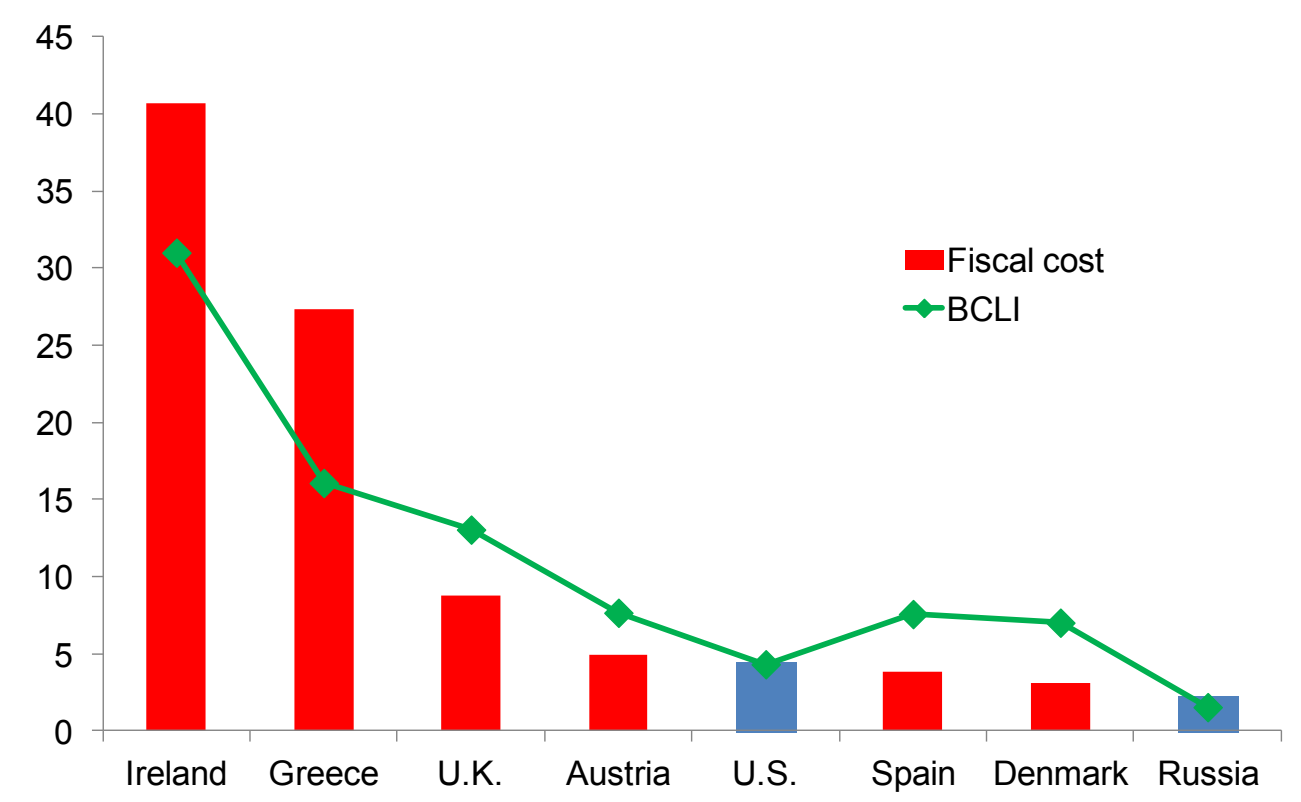

Source: Laeven and Valencia (2013).

Note: Fiscal costs include direct fiscal outlays committed to the financial sector from the start of the crisis up to end-2011. The green line indicates the maximum level of the BCLI for each country during 2007-11. The red bars indicate countries with relatively high contingent liability risk according to the BCLI (i.e. a BCLI score of 7 or above which includes one-third of the countries in the sample).

\footnotetext{
${ }^{10}$ Similarly, in Arslanalp and Liao (2014), we find that changes in the BCLI have a statistically significant impact on sovereign CDS spreads for a panel of advanced and emerging market economies (using an earlier version of the BCLI).
} 


\section{G. Bank-by-Bank Estimates}

The BCLI can also be used to assess the contribution of individual banks to the overall risk index. For example, Figure 5 shows the contribution to overall risk of the 4 largest Australian banks - Australia and New Zealand Banking Group, Commonwealth Bank of Australia, National Australia Bank and Westpac Banking Corporation - and that of the other banks in Australia (see Appendix Table 2 for the full sample). Given their relatively large size in the banking sector, Australia has a long-standing policy (the "four pillars" policy) that effective rejects any mergers between these four banks.

To estimate their marginal contribution to the BCLI, we took out each bank at a time from the full country sample and calculated the amount of the decline in the BCLI as a result. This decline is attributed to each bank's contribution to the overall contingent liability risk.

The exercise allows us to show that in Australia the four largest banks account for the bulk of the contingent liability risk as captured by the BCLI (Figure 5), although the overall BCLI for Australia is relatively low compared to that of other advanced economies (Figure 1).

Figure 5. Banking Sector Contingent Liability Index (BCLI) for Australia, 2006-13 (Percent of GDP)

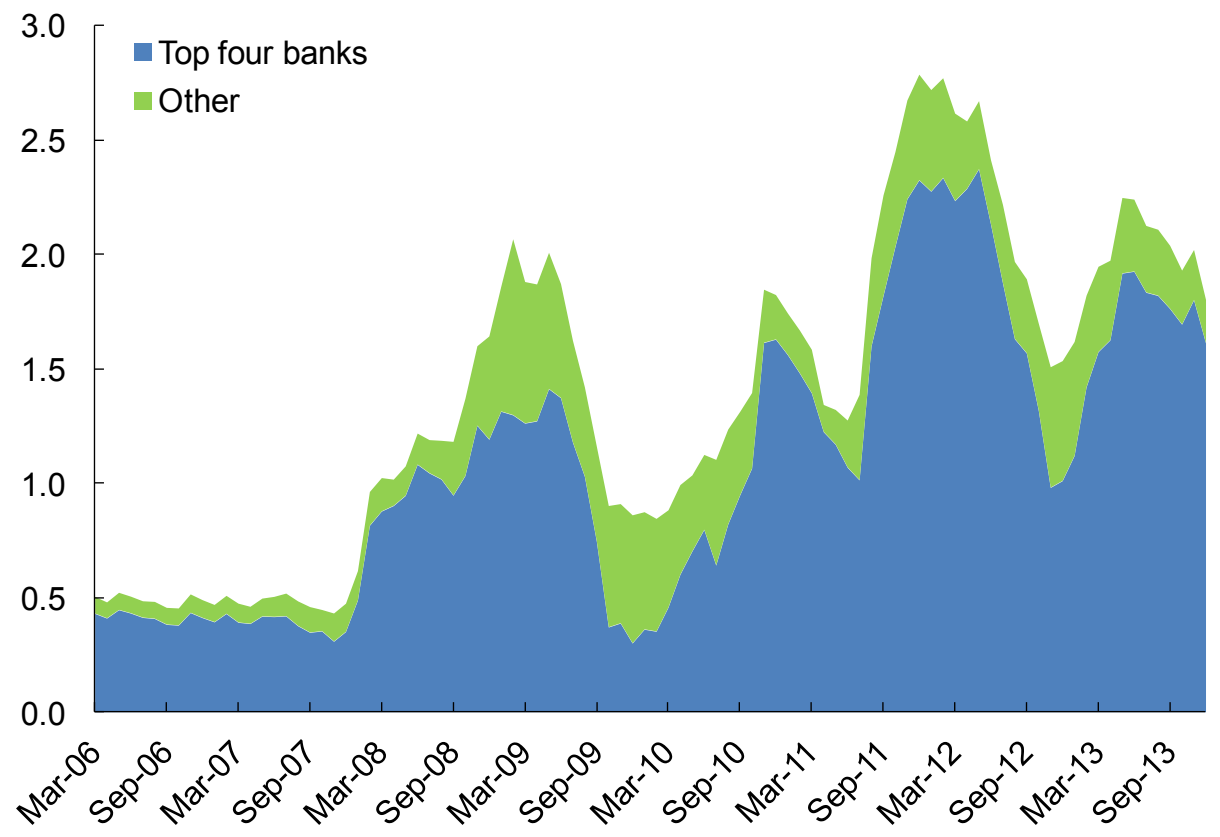

Source: Authors' calculations. 


\section{H. Global Systemically Important Banks (G-SIBs)}

Another possible application of the BCLI is to monitor the contingent liability related to all (or a group of) large global systemically important banks (G-SIBs). This could be useful from a global banking regulatory perspective, including monitoring the impact of Basel III reforms aimed at reducing implicit government support available to systemic banks.

In that context, Figure 6 shows the estimated contingent liability risk (in U.S. dollars) related to 30 banks categorized as G-SIBs by the Financial Stability Board as of November 2014, except for ING Bank for which we do not have data. ${ }^{11}$ The figure shows that these liabilities started rising in late 2007, reached a peak in March 2009, and has been declining since then (except for 2011, when the euro area debt crisis erupted).

The decline in the BCLI since the global financial crisis can be attributed to a number of factors that feed directly into the calculation of the BCLI, namely the deleveraging and derisking of banks' balance sheets ( $\mathrm{L}$ and $\mathrm{pd})$, reduced distress correlation among banks $(\rho)$, and lower perceived state support (pss), as assessed by rating agencies. In turn, some of these can be tied to recent regulatory efforts such as the European Union's Bank Recovery and Resolution Directive (BRRD) aimed to reduce the probability of state support.

Figure 6. Banking Sector Contingent Liability Index (BCLI) for G-SIBs, 2006-13

(Trillions of U.S. dollars)

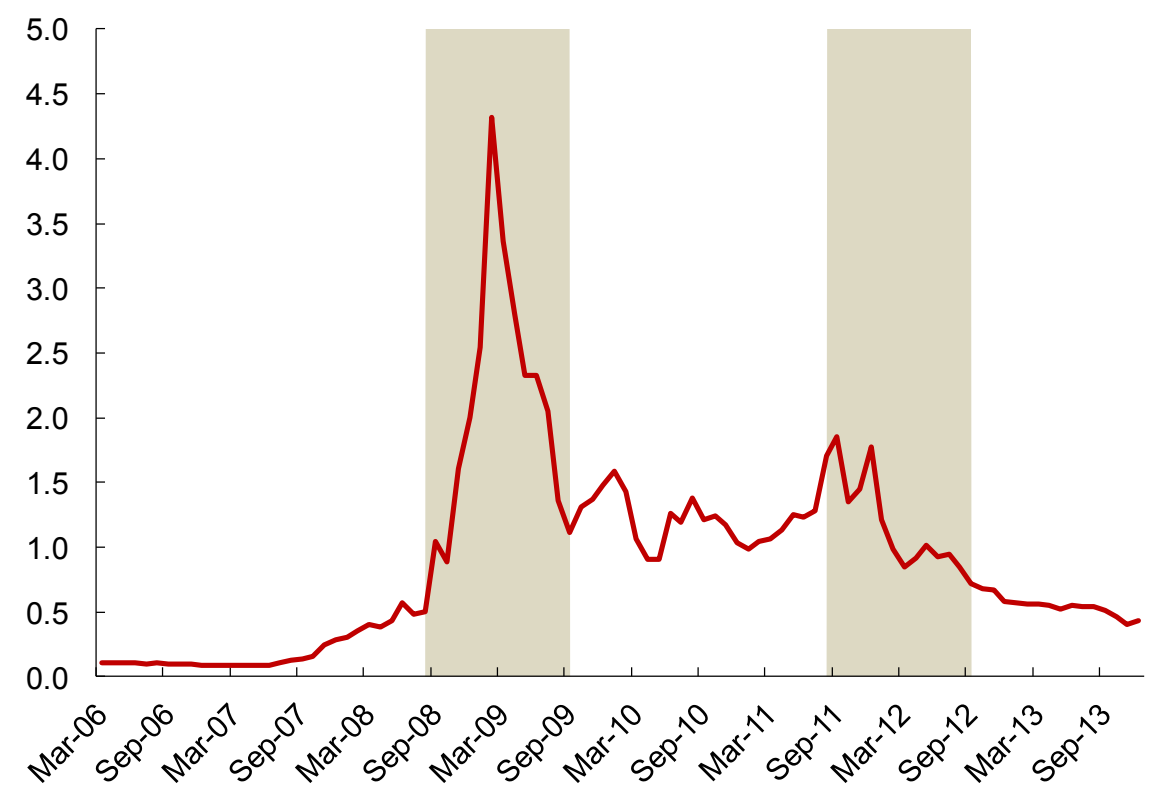

Source: Authors' calculations

Note: The shaded areas represent the global financial crisis of 2008-09 and the euro area debt crisis of 2011-12.

\footnotetext{
${ }^{11}$ To aggregate the BCLI across countries for this exercise, we calculate the BCLI using total bank liabilities $\left(\mathrm{l}_{\mathrm{it}}\right)$ expressed in U.S. dollars, rather than in percent of home country GDP.
} 


\section{Limitations of the BCLI}

There are three main limitations of the BCLI. First, the BCLI does not (and is not meant to) provide a measure of all costs (direct and indirect) of bank crises, only the direct costs of fiscal outlays committed to bank support operations. Second, the BCLI does not attempt to provide a measure of the net fiscal cost (after asset recoveries) of fiscal outlays, only their upfront gross cost. Third, to the extent that there are measurement errors in the proxies used in the construction of the BCLI (in particular on probability levels), the BCLI may overstate or understate the true contingent liability. However, even if that is the case, as we showed in the previous section and discuss further below, the BCLI can be a useful tool for rankordering countries or monitoring changes in contingent liabilities over time.

Wider costs of a banking crisis. The BCLI captures only the direct fiscal cost of bank failures. It does not try to capture the wider damage to the economy from a banking crisis in terms of the loss of output and loss of government revenues. These "indirect" costs could be substantially larger than the direct costs in terms of their magnitude and contribution to the rise in public debt levels after a banking crisis (Laeven and Valencia, 2013).

Net cost versus gross cost. Similarly, the BCLI provides an estimate of the upfront gross fiscal cost, not the eventual "net" cost of bank support operations. In some cases, public intervention in banks can generate significant upside. For example, the U.S. authorities have recovered more than the full cost of their initial public support to the financial system in 2008-09. In contrast, the U.K. has recovered only about a quarter of the cost, as of end-2014 (IMF, 2015). In practice, it is difficult to know how much will be recovered after a bank bailout. Hence, we do not attempt to capture the recovery rate in the BCLI. ${ }^{12}$

Potential measurement errors. Of course, any summary index is sensitive to the proxies used in constructing the index. Therefore, we do not propose the BCLI as a substitute for judicious consideration of all risk indicators. Nevertheless, as we show in the previous section, the BCLI appears to be a useful tool for rank ordering countries in terms of their contingent liability risk. Moreover, even if some of the proxies used in the index may be over (or under) stated, their trends can provide important information on the evolution of banking sector risks. ${ }^{13}$ That is also why we recommend using the BCLI in empirical studies in first differences (see Arslanalp and Liao, 2014).

\footnotetext{
${ }^{12}$ Historically, the average recovery rate in banking crises has been around 25 percent of the gross fiscal cost, although the variance around this number is large (Laeven and Valencia, 2013). The recovery rate can vary depending on asset quality and collateralization levels. Another important consideration is the presence of bail-inable liabilities, which can reduce the net fiscal cost of supporting distressed banks.

${ }^{13}$ For example, the EDF measure used as a proxy for the probability of bank distress has been found to have worked well in rank ordering defaulters during the global financial crisis, even if EDF levels were conservative (i.e., somewhat higher than subsequently realized default rates) before the crisis (see Appendix 1).
} 


\section{Conclusion}

In this paper we have developed an indicator, the BCLI, to assess potential losses to the government that could arise from bank failures and have illustrated its use for individual countries and groups of banks. Going forward, there could be a number of applications of this work.

- $\quad$ First, partly because contingent liabilities from banks are difficult to gauge, empirical studies on the relationship between contingent liabilities and sovereign risk have been limited, as we highlight in Arslanalp and Liao (2014). This paper takes a step toward filling this gap by providing an index that could be used for further empirical studies.

- $\quad$ Second, the BCLI could be a useful surveillance tool for monitoring risks to public debt sustainability. Indeed, a recent IMF survey of 117 countries (IMF, 2015) found that (i) measuring risks to public debt from the financial sector is not adequately done prior to the materialization of risks; (ii) assessing implicit contingent liabilities is typically only done under special circumstances; and (iii) while governments seem to have adequate access to information about financial sector risks, the link to public finances is rare even in countries with high public debt, large and leveraged banking sectors, or with history of banking crises.

- $\quad$ Third, the BCLI could help assess the impact of bank regulatory reforms aimed at reducing implicit government support available to banks. For example, the European Union's Bank Recovery and Resolution Directive (BRRD) that comes into effect on January 2016 should reduce the probability of state support (pss), while initiative such as the Financial Stability Board (FBS)'s total loss-absorbing capacity (TLAC) rule should reduce the loss given default $(\alpha)$ parameters of our index. ${ }^{14}$ As a result, such regulatory reforms should show up as a decline in the BCLI.

- $\quad$ Finally, since the methodology behind the BCLI is quite general, the approach can be extended beyond banks to create an index to track contingent liability risks from corporates, including state-owned enterprises and quasi-sovereign entities. This may be useful for countries where the corporate-sovereign nexus is strong, or likely to become stronger due to rising corporate sector vulnerabilities.

\footnotetext{
14 The TLAC rule, which comes into force in 2019, will apply to all global systemically important banks.
} 


\section{References}

Allen, F. and D. Gale, 1994, "Limited Market Participation and Volatility of Asset Prices," American Economic Review 84, 933-955.

Arslanalp, S. and Y. Liao, 2014, "Banking Sector Contingent Liabilities and Sovereign Risk," Journal of Empirical Finance, Volume 29 (December).

Acharya, V., I. Drechsler, and P. Schnabl, 2014, "A Pyrrhic Victory? Bank Bailouts and Sovereign Credit Risk," Journal of Finance, 69(9), December 2014

Amaglobeli, D., N. End, M. Jarmuzek, and G. Palomba, 2015, "From Systemic Banking Crises to Fiscal Costs: Risk Factors," IMF Working Paper 15/166 (Washington: IMF)

Asonuma, T., S. Bakhache, and H. Hesse, 2015, “Is Banks' Home Bias Good or Bad for Public Debt Sustainability,” IMF Working Paper 15/44 (Washington: IMF)

Berndt A., R. Douglas, D. Duffie, M. Ferguson, D. Schranz, 2005, "Measuring Default-Risk Premia from Default Swap Rates and EDFs," Stanford University (November)

Bohn, J., N. Arora, and I. Korablev, 2005 "Power and Level Valuation of the EDF Credit Measures in the U.S. Market,” Moody's KMV (April).

Brandao-Marques, L., R. Correa, and H. Sapriza, 2013, “International Evidence on Government Support and Risk Taking in the Banking Sector" Federal Reserve International Finance Discussion Papers, Number 1086 (August)

Cebotari, A., 2008, “Contingent Liabilities: Issues and Practice,” IMF Working Paper 08/245 October 2008 (Washington: International Monetary Fund).

Claessens, S., and D. Klingebiel, 2002, "Measuring and Managing Government Contingent Liabilities in the Banking Sector," in Government at Risk: Contingent Liabilities and Fiscal Risk, edited by H. Polackova Brixi and A. Schick (Washington: World Bank)

Correa, R. and H. Sapriza, 2014, "Sovereign Debt Crises," Federal Reserve International Finance Discussion Papers, Number 1104 (May)

Crossen, C. and X. Zhang., 2011, "Validating the Public EDF Model for Global Financial Firms," Moody's Analytics (October).

Duffie D., L. Saita, and K. Wang, 2007, "Multi-period Corporate Default Prediction with Stochastic Covariates," Journal of Financial Economics, Vol. 83, No. 3, (March).

FDIC, 2003, "A Portfolio Perspective for Evaluating the Adequacy of the Insurance Funds" December 10, 2003, https://www.fdic.gov/bank/analytical/fyi/2003/121003fyi.html 
Fitch Ratings, 2013, Definitions of Ratings and Other Forms of Opinion (February).

Gerlach, S., A. Schulz, and G. B. Wolff, 2010, "Banking and Sovereign Risk in the Eurozone”, Deutsche Bundesbank Discussion Paper 09/2010

Harada, K., T. Ito, S. Takahashi, 2010, "Is the Distance to Default a Good Measure in Predicting Bank Failures? Case Studies,” NBER Working Paper 16182

Hoggarth, G., R. Reis, V. Saporta, 2002, "Costs of Banking System Instability: Some Empirical Evidence," Journal of Banking and Finance 26 (5), 825-855.

Hull, J. C., 2000, Options, Futures, and Other Derivatives, $4^{\text {th }}$ edition, Prentice Hall.

International Monetary Fund, 2001, Government Finance Statistics Manual (Washington: International Monetary Fund).

, 2014, "How Big Is the Implicit Subsidy For Banks Considered Too Big To Fail?" GFSR Chapter 3, April (Washington: International Monetary Fund).

, 2015, "Banking to Sovereign Stress: Implications for Public Debt", January (Washington: International Monetary Fund).

Irwin. T., 2007, "Government Guarantees Allocating and Valuing Risk in Privately Financed Infrastructure Projects," Washington, DC: World Bank.

Laeven L., and F. Valencia, 2010, "Resolution of Banking Crises: The Good, the Bad, and the Ugly," IMF Working Paper No. 12/146 (June).

Laeven L., and F. Valencia, 2013, "Systemic Banking Crises Database," IMF Economic Review, vol. 61(2), pages 225-270, June.

Merton, R.C., 1974, "On the Pricing of Corporate Debt: The Risk Structure of Interest Rates," Journal of Finance, 29(2): 449-470.

Moody's, 2012, "Public Firm Expected Default Frequency (EDF) Credit Measures: Methodology, Performance, and Model Extensions," Capital Markets Research.

Munves D. W., A. Smith, and D. T. Hamilton, 2010, "Banks and their EDF Measures Now and Through the Credit Crisis: Too High, Too Low, or Just About Right?” Moody's Analytics, Capital Markets Research (December).

Reinhart, C, M, and K. S. Rogoff, 2009, "This Time Is Different: Eight Centuries of Financial Folly," Princeton, New Jersey: Princeton University Press.

Schich, S. and Y. Aydin, 2014, "Measurement and Analysis of Implicit Guarantees of Bank Debt: Key Findings from OECD Survey," OECD Journal: Financial Market Trends. 
Sellers, M., and N. Arora, 2004, "Financial EDF Measures: A New Model of Dual Business Lines," Moody’s Analytics Technical Paper (August).

Shleifer, A., and R. Vishny, 1992, "Liquidation Values and Debt Capacity: A Market Equilibrium Approach,” Journal of Finance, Vol. 47, iss. 4, pp. 1343-1366.

Ueda, K. and B. Weder di Mauro, 2013, "Quantifying Structural Subsidy Values for Systemically Important Financial Institutions," Journal of Banking and Finance (37): 3830-3842. 


\section{Appendix 1. Moody's Expected Default Frequency (EDF)}

EDF is a credit risk measure calculated by Moody's to assess the probability that a firm will default over a specified period of time, typically one year. According to the Moody's EDF model, a firm defaults when the market value of its assets (the value of the ongoing business) falls below its liabilities payable (the default point).

There are three key values that determine a firm's EDF credit measure: (i) the current market value of the firm (market value of assets); (ii) the level of the firm's obligations (default point); and (iii) the vulnerability of the market value to large changes (asset volatility).

The market value of assets is determined by the firm's equity value, equity volatility, and liability structure. Because the market value of assets is not directly observable, Moody's employs a Merton (1974) type of model to compute this value, which treats the firm's equity value as a call option on the firm's underlying assets. The default point is the level of the market value of a company's assets, below which the firm would fail to make scheduled debt payments. The default point is firm specific and is a function of the firm's liability structure. It is estimated based on the ongoing research by Moody's, observing each firm's default point at the time of default. ${ }^{15}$ The asset volatility of the firm is a measure of the business risk of the firm. It is measured by the standard deviation of the annual percentage change in the market value of the firm's assets. The riskier the business model of the firm, the higher the asset volatility, and the more likely the firm's value will fall below its default point.

The EDF credit measure exhibits a number of properties that distinguishes it from other measures of distress probability. In particular:

- $\quad$ First, EDF measures - because they are based on equity markets - are dynamic and forward-looking, in contrast to measures that rely on backward-looking indicators, such as balance sheet or accounting data.

- $\quad$ Second, EDFs are calibrated to actual default rates. ${ }^{16}$ Specifically, the relationship between the EDF and distance to default (i.e., the number of standard deviations between the market value of assets and the default point) is not assumed to be a normal distribution, as in the Merton (1974) model, but mapped to historical default rates. As such, it is intended to capture tail risk events more appropriately. For example, a firm with a distance to default of four has a near zero ( 0.003 percent) likelihood of defaulting under the normality assumption, whereas the EDF's empirical mapping indicates a 0.4 percent probability of default (Moody's, 2012).

\footnotetext{
${ }^{15}$ In the EDF model, four broad types of credit events are considered defaults: (i) missed payments; (ii) bankruptcy, administration, receivership, or legal equivalent; (iii) distressed debt restructuring; and (iv) government bailouts enacted to prevent a credit event.

${ }^{16}$ The latest EDF measures, version 9.0, are calibrated with more than 10,700 defaults going back to 1973, including almost 4,000 defaults from outside North America. They also include increased number of financial firm defaults that occurred during the global financial crisis.
} 
- Third, EDFs reflect "actual" default probabilities, as opposed to "risk-neutral" default probabilities derived from credit default swap (CDS) or bond spreads. As discussed in Hull (2000), "risk-neutral" probabilities of default are appropriate for asset pricing, but only "actual" probability measures, such as EDFs, should be used as a measure of potential losses. This is because "risk-neutral" default probabilities incorporate a compensation for price of risk, and hence, are almost always higher than actual default rates.

- $\quad$ Finally, CDS or bond spreads would understate the true probability of bank distress, if there is an expectation that the government would bail out bank creditors, but not equity holders. EDF measures are largely free of that effect, as they are based on equity prices and government support to banks usually exclude shareholders. ${ }^{17} 18$

A number of empirical studies have been undertaken to evaluate the accuracy of EDF as a credit risk indicator. Bohn and others (2005) test the performance of EDF measures in the U.S. during 1996-2004, and find that EDF is a superior measure to other credit risk measures, such as credit ratings, z-scores, and simpler versions of the Merton (1974) model. Sellers and Arora (2004) find that over this period the accuracy ratio for EDF was 0.83 while the ratio for credit ratings was 0.73 . Duffie, Saita, and Wang (2007) find that a more elaborate default prediction model using covariates other than distance to default achieves an accuracy ratio that is only slightly higher than that of the EDF during 2000-04.

These results are not only exclusive to non-financial firms. Munves, Smith, and Hamilton (2010) explore the performance of the EDF model for financial institutions and find that EDF measures worked well in rank ordering defaulters during the global financial crisis: financial institutions that subsequently defaulted had high EDFs relative to their peers. Harada, Ito, and Takahashi (2010) examine the movements of the distance to default (DD) - the distance between the market value of assets and the default point divided by the standard deviation of assets - of eight Japanese banks that failed Japanese banking crisis. They find that the DD was generally a reliable measure in predicting bank failures: the DD became smaller in anticipation of failure in many cases, and the DD spread, defined as the DD of a failed bank minus the DD of sound banks, also provided a useful indicator. Crossen and Zhang (2011) find that the EDF model's predictive power during the post-crisis period (2008-10) was consistent with its previous history (2001-07), outperforming alternative risk measures, including credit ratings. If anything, they find that EDF levels were conservative (i.e., somewhat higher than subsequently realized default rates) before the crisis when compared with later-realized default rates.

\footnotetext{
${ }^{17}$ A good example is the experience of Fannie Mae and Freddie Mac in 2008. In the weeks leading up to the decision to take those agencies into government conservatorship, the agencies' equity prices and EDFs signaled distress. However, agency bonds yields remained relatively stable, given the expectation that bond holders would be protected under a bailout. Indeed, bond holders were protected while shareholders incurred losses.

${ }^{18}$ Alternatively, since CDS and bond markets are usually less liquid than equity markets, they can overstate the actual likelihood of default due to the presence of a liquidity premium.
} 


\section{Appendix 2. Fitch's Support Ratings}

Fitch's Support Ratings (SRs) reflect the rating agency's view on the likelihood that a financial institution will receive extraordinary support, in case of need, to prevent it defaulting on its senior obligations (Fitch Ratings, 2013). Extraordinary support typically comes from one of two sources: the rated entity's parent/shareholders (institutional support) or the national authorities of the country where it is domiciled (sovereign support).

SRs are assigned on a five-point scale, with 1 representing an extremely high probability of support, and 5 indicating that support cannot be relied on. SRs do not assess the intrinsic credit quality of a bank. Rather they communicate Fitch's judgment on whether the bank would receive support should the financial institution become distressed. They are predicated on the assumption that any necessary support is provided on a timely basis and is sufficiently sustained so that the bank being supported is able to continue meeting its senior obligations, such as secured and unsecured senior debt and insured and uninsured deposits, until the crisis is over (Fitch Ratings, 2014).

Support Rating Floors (SRFs) reflect Fitch's view about the likelihood that the rated entity will receive extraordinary support, in case of need, specifically from government authorities. SRFs therefore do not capture the potential for institutional support from the entity's shareholders. They are assigned where Fitch believes the most likely source of potential extraordinary support is government authorities, rather than the bank's shareholders. SRFs are assigned on the "AAA" rating scale. Where there is no reasonable assumption that sovereign support would be forthcoming, an SRF of "No Floor" is assigned.

SRFs are determined based on three factors:

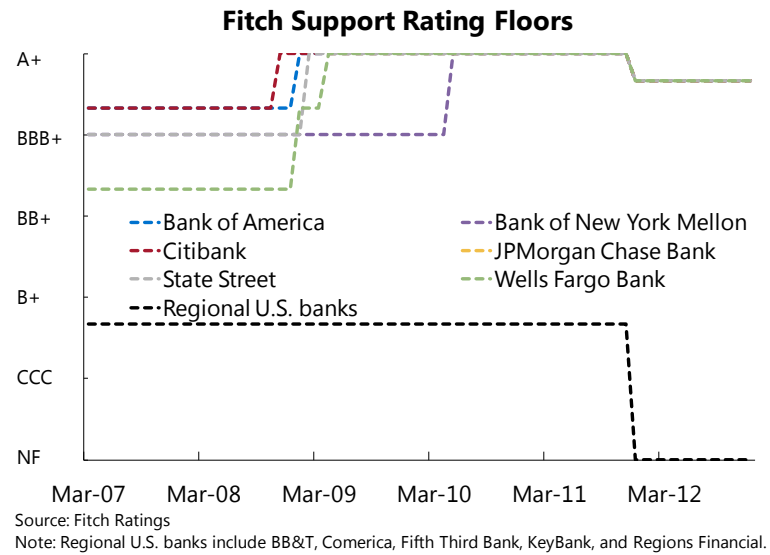

(i) sovereign's ability to support; (ii) sovereign's propensity to support the banking sector; and (iii) sovereign's propensity to support a specific financial institution. The propensity to support is a judgment made by Fitch, while the ability to support is set by the sovereign's own default rating. Global regulatory initiatives to reduce implicit government support to banks are also factored into the SRs and SRFs to the extent that they affect a government's ability or propensity to provide timely support. ${ }^{19}$

\footnotetext{
${ }^{19}$ A recent example is from Fitch Ratings' press release on August 27, 2014 regarding Singapore's three largest banks (DBS, OCBC, and UOB): "The SRs and SRFs for the three Singapore banks reflect Fitch's view that the state is extremely likely to provide extraordinary support to the banks, if necessary. This is due to their high systemic importance, with around 60 percent of the Singapore-dollar deposit base, and the sovereign's strong financial ability to provide support, based on its 'AAA' ratings. A change in the government's ability or propensity to provide timely support would be negative for the three banks' SRs and SRFs. This may be triggered by global regulatory initiatives aimed at reducing implicit government support available to banks."
} 
We map SRFs into probabilities of state support (pss), as shown in Appendix Table 1. An SRF of "AAA" translates into a pss of 1, given the extremely high probability of external support assessed by Fitch. In contrast, an SRF of "No Floor" is assigned a pss of 20 percent, given Fitch's guidance (Fitch Ratings, 2013) that a No Floor rating reflects a probability of support of less than 40 percent (we took the average between 0 and 40 percent given that "No Floor" could represent any probability below 40 percent). Meanwhile, a rating of "C" a notch above the "No Floor" rating - gets a pss of 40 percent. All other ratings are assigned a pss ranging from 0.4 to 1 through linear mapping.

Appendix Table 1. Mapping Support Rating Floors to Probabilities of State Support

\begin{tabular}{cccc}
\hline Support Rating (SR) & Description by Fitch & Support Rating Floor (SRF) & Probability of State Support (PSS) \\
\hline 1 & Extremely high probability of & AAA & 1.00 \\
& external support & AA+ & 0.97 \\
& & AA & 0.93 \\
& & AA- & 0.90 \\
& & $\mathrm{~A}+$ & 0.87 \\
& & $\mathrm{~A}$ & 0.83 \\
2 & High probability of external & $\mathrm{ABB}+$ & 0.80 \\
& support & $\mathrm{BBB}$ & 0.77 \\
& & $\mathrm{BBB}-$ & 0.73 \\
3 & & $\mathrm{BB}+$ & 0.70 \\
& & $\mathrm{BB}$ & 0.67 \\
& Moderate probability of & $\mathrm{BB}-$ & 0.63 \\
4 & external support & $\mathrm{B}+$ & 0.60 \\
& & $\mathrm{~B}$ & 0.57 \\
5 & Limited probability of & $\mathrm{B}-$ & 0.53 \\
& external support & $\mathrm{CCC}$ & 0.50 \\
& External support not reliable & $\mathrm{CC}$ & 0.47 \\
& & $\mathrm{C}$ & 0.43 \\
& & $\mathrm{NF}$ & 0.40 \\
& & & 0.20 \\
\hline
\end{tabular}




\section{Appendix 3. Sample of Banks}

To illustrate the BCLI, we compiled a sample of 258 banks in 32 advanced and emerging market economies. Appendix Table 2 provides the full sample of banks, headquartered in the following countries:

- $\quad$ Advanced economies (20): Australia, Austria, Canada, Denmark, Finland, France, Germany, Greece, Ireland, Italy, Japan, Korea, Norway, Portugal, Singapore, Spain, Sweden, Switzerland, the United Kingdom, and the United States.

- $\quad$ Emerging market economies (12): Brazil, Chile, China, Colombia, India, Indonesia, Malaysia, Philippines, Russia, South Africa, Thailand, and Turkey.

In each country, the sample was built by including the largest banks (in descending order of their size), so as to cover at least half — and usually more than 80 percent — of the national banking system (i.e. excluding foreign subsidiaries), as expressed in terms of total assets. ${ }^{20}$ Asset size is measured at the banking group level (i.e. on a consolidated basis) covering all subsidiaries and branches inside and outside the bank's country of headquarters.

\footnotetext{
${ }^{20}$ For example, Bank Austria, a large bank operating in Austria, is not in the sample for Austria but is included in the sample for Italy since it is a subsidiary of Unicredit, a bank headquartered in Italy.
} 


\section{Appendix Table 2. Sample of Banks (Advanced Economies)}

\begin{tabular}{|c|c|c|c|c|c|}
\hline Country & Coverage & Bank & Country & Coverage & Bank \\
\hline \multirow[t]{8}{*}{ Australia } & 8 & Australia and New Zealand Banking Group & Korea & 7 & Woori Financial Group \\
\hline & & Bank of Queensland Ltd & & & Hana Financial Group \\
\hline & & Bendigo and Adelaide Bank Ltd & & & Industrial Bank of Korea \\
\hline & & Commonwealth Bank of Australia & & & KB Financial Group \\
\hline & & Macquarie Group Ltd & & & Korea Exchange Bank (until Feb 2012) \\
\hline & & National Australia Bank Ltd & & & NH Financial Group \\
\hline & & Suncorp Group Ltd & & & Shinhan Financial Group \\
\hline & & Westpac Banking Corporation & Norway & 5 & DnB Bank ASA \\
\hline \multirow[t]{5}{*}{ Austria } & 5 & BAWAG PSK Group & & & Sparebank 1 Nord-Norge \\
\hline & & Erste Group Bank AG & & & SpareBank 1 SMN \\
\hline & & Hypo Alpe-Adria-Group & & & SpareBank 1 SR-Bank \\
\hline & & Oesterreichische Volksbank AG & & & Sparebanken Vest \\
\hline & & Raiffeisen Bank International (RBI) & Portugal & 5 & Banco BPI SA \\
\hline \multirow[t]{9}{*}{ Canada } & 9 & Bank of Montreal & & & Banco Comercial Portugues SA (BCP) \\
\hline & & Bank of Nova Scotia & & & Banco Internacional do Funchal SA (BANIF) \\
\hline & & Canadian Imperial Bank of Commerce (CIBC) & & & Caixa Geral de Depositos SA \\
\hline & & Canadian Western Bank & & & Espirito Santo Financial Group SA (ESFG) \\
\hline & & Laurentian Bank of Canada & Singapore & 3 & DBS Group Holdings \\
\hline & & Manulife Bank of Canada & & & Oversea-Chinese Banking Corporation (OCBC) \\
\hline & & National Bank of Canada & & & United Overseas Bank (UOB) \\
\hline & & Royal Bank of Canada (RBC) & Spain & 8 & Banco De Sabadell SA \\
\hline & & Toronto-Dominion Bank & & & Banco Popular Espanol SA \\
\hline \multirow[t]{3}{*}{ Denmark } & 3 & Danske Bank & & & BBVA \\
\hline & & Jyske Bank & & & BFA-Bankia \\
\hline & & Sydbank & & & Caixabank SA (formerly Caja de Ahorros y Pensiones de Barcelona) \\
\hline \multirow[t]{3}{*}{ Finland } & 3 & Aktia Bank Plc & & & Catalunya Caixa \\
\hline & & Bank of Aland Plc & & & Nova Caixa Galicia \\
\hline & & Pohjola Bank Plc & & & Santander \\
\hline \multirow[t]{5}{*}{ France } & 5 & Banque Federative du Credit Mutuel & Sweden & 4 & Nordea Bank AB \\
\hline & & BNP Paribas & & & Skandinaviska Enskilda Banken AB (SEB) \\
\hline & & Groupe BPCE & & & Svenska Handelsbanken AB \\
\hline & & Group Credit Agricole & & & Swedbank $A B$ \\
\hline & & Societe Generale & Switzerland & 8 & UBS AG \\
\hline \multirow[t]{11}{*}{ Germany } & 11 & Bayerische Landesbank & & & Banque Cantonale Vaudoise \\
\hline & & Commerzbank AG & & & Basler Kantonalbank \\
\hline & & Deutsche Bank AG & & & Berner Kantonalbank AG \\
\hline & & DZ Bank AG & & & Credit Suisse Group AG \\
\hline & & HSH Nordbank $A G$ & & & Luzerner Kantonalbank AG \\
\hline & & Hypo Real Estate Holding AG & & & St. Galler Kantonalbank AG \\
\hline & & Landesbank Baden-Wuerttemberg & & & Valiant Holding \\
\hline & & Landesbank Berlin Holding (LBB) & United Kingdom & 7 & Barclays Plc \\
\hline & & Landesbank Hessen-Thüringen GZ (HELABA) & & & HBOS Plc (until Dec 2008) \\
\hline & & Norddeutsche Landesbank GZ (Nord/LB) & & & HSBC Holdings PIc \\
\hline & & WestLB AG & & & Lloyds Banking Group PIc \\
\hline \multirow[t]{6}{*}{ Greece } & 6 & Agricultural Bank of Greece SA (ATEbank) & & & Northern Rock (until Jan 2008) \\
\hline & & Alpha Bank & & & Royal Bank of Scotland Group PIc \\
\hline & & Eurobank Ergasias SA & & & Standard Chartered Plc \\
\hline & & National Bank of Greece SA & United States & 27 & American Express Company \\
\hline & & Piraeus Bank SA & & & Bank of America Corporation \\
\hline & & TT Hellenic Postbank SA & & & Bank of New York Mellon Corporation \\
\hline \multirow[t]{4}{*}{ Ireland } & 4 & Allied Irish Banks Plc & & & BB\&T Corporation \\
\hline & & Anglo Irish Bank (until Dec 2008) & & & Bear Stearns Companies Inc (until Mar 2008) \\
\hline & & Bank of Ireland & & & Capital One \\
\hline & & Permanent TSB PIc (formerly Irish Life \& Permanent) & & & Citigroup Inc \\
\hline Italy & 5 & Banca Monte dei Paschi di Siena SpA & & & Comerica Inc \\
\hline & & Banco Popolare & & & Discover Financial Services \\
\hline & & Intesa Sanpaolo & & & Fifth Third Bancor \\
\hline & & UniCredit SpA & & & Goldman Sachs Group, Inc \\
\hline & & Unione di Banche Italiane Scpa (UBI Banca) & & & Huntington Bancshares Inc \\
\hline Japan & 15 & Bank of Yokohama & & & JP Morgan Chase \& Co. \\
\hline & & Chiba Bank & & & KeyCorp \\
\hline & & Fukuoka Financial Group & & & Lehman Brothers Holdings Inc (until Sep 2008) \\
\hline & & Hokuhoku Financial Group & & & M\&T Bank Corporation \\
\hline & & Joyo Bank & & & Merrill Lynch \& Co Inc (until Sep 2008) \\
\hline & & Mitsubishi UFJ Financial Group & & & Morgan Stanley \\
\hline & & Mizuho Financial Group & & & PNC Financial Services Group Inc \\
\hline & & Nishi-Nippon City Bank & & & Regions Financial Corporation \\
\hline & & Norinchukin Bank & & & State Street Corporation \\
\hline & & Resona Holdings & & & SunTrust Banks, Inc. \\
\hline & & Sapporo Hokuyo Holdings & & & U.S. Bancorp \\
\hline & & Shinsei Bank & & & Wachovia Corporation (until Sep 2008) \\
\hline & & Shizuoka Bank & & & Washington Mutual Inc (until Sep 2008) \\
\hline & & Sumitomo Mitsui Financial Group & & & Wells Fargo \& Company \\
\hline & & Yamaguchi Financial Group & & & Zions Bancorporation \\
\hline
\end{tabular}

\section{CInternational Monetary Fund. Not for Redistribution}


Appendix Table 2. Sample of Banks (Emerging Market Economies)

\begin{tabular}{|c|c|c|c|c|c|}
\hline Country & Coverage & Bank & Country & Coverage & Bank \\
\hline \multirow[t]{6}{*}{ Brazil } & 6 & Banco Bradesco SA & Indonesia & 9 & Bank Central Asia \\
\hline & & Banco do Brasil SA & & & Bank Danamon Indonesia Tbk \\
\hline & & Banco Nacional de Desenvolvimento Economico e Social ( & BNDES) & & Bank Internasional Indonesia (until Sep 2008) \\
\hline & & Caixa Economica Federal & & & Bank Mandiri \\
\hline & & Itau Unibanco Holdings & & & Bank Mega \\
\hline & & Unibanco (until Feb 2009) & & & Bank Negara Indonesia (Bank BNI) \\
\hline \multirow[t]{4}{*}{ Chile } & 4 & Banco de Chile & & & Bank Pan Indonesia (Panin Bank) \\
\hline & & Banco de Credito e Inversiones (BCl) & & & Bank Rakyat Indonesia (Bank BRI) \\
\hline & & CorpBanca & & & Bank Tabungan Negara (Bank BTN) \\
\hline & & Grupo Security & Malaysia & 9 & Affin Holdings Bhd \\
\hline \multirow[t]{14}{*}{ China } & 14 & Agricultural Bank of China & & & Alliance Financial Group Bhd \\
\hline & & Bank of Beijing & & & AMMB Holdings Bhd \\
\hline & & Bank of China & & & CIMB Group Holdings Bhd \\
\hline & & Bank of Communications & & & EON Capital Bhd (until May 2011) \\
\hline & & China CITIC Bank & & & Hong Leong Financial Group Bhd \\
\hline & & China Construction Bank & & & Malayan Banking Bhd (Maybank) \\
\hline & & China Everbright Bank & & & Public Bank Bhd \\
\hline & & China Merchants Bank & & & RHB Capital Bhd \\
\hline & & China Minsheng Banking Corporation & Philippines & 8 & Bank of the Philippine Islands (BPI) \\
\hline & & Hua Xa Bank & & & BDO Unibank \\
\hline & & Industrial \& Commercial Bank of China (ICBC) & & & China Banking Corporation (Chinabank) \\
\hline & & Industrial Bank & & & Metropolitan Bank \& Trust Company \\
\hline & & Ping An Bank & & & Philippine National Bank \\
\hline & & Shanghai Pudong Development Bank & & & Rizal Commercial Banking Corp. (RCBC) \\
\hline \multirow[t]{5}{*}{ Colombia } & 5 & Banco Davivienda & & & Security Bank Corporation \\
\hline & & Banco de Bogota & & & Union Bank of the Phlilippines \\
\hline & & Banco de Occidente & Russia & 10 & Alfa-Bank OJSC \\
\hline & & Banco Popular & & & Bank of Moscow (until Dec 2011) \\
\hline & & Bancolombia & & & Bank Saint-Petersburg \\
\hline \multirow[t]{29}{*}{ India } & 24 & Allahabad Bank & & & Gazprombank \\
\hline & & Andhra Bank & & & MDM Bank \\
\hline & & AXIS Bank Limited & & & NOMOS-Bank \\
\hline & & Bank of Baroda & & & Promsvyazbank \\
\hline & & Bank of India & & & Sberbank \\
\hline & & Bank of Maharashtra & & & TransCreditBank (until Dec 2010) \\
\hline & & Canara Bank & & & VTB Bank \\
\hline & & Central Bank of India & South Africa & 6 & African Bank Investments Ltd \\
\hline & & Corporation Bank & & & Capitec Bank Holdings Ltd \\
\hline & & Dena Bank & & & FirstRand Bank Ltd \\
\hline & & HDFC Bank Ltd & & & Investec Bank Ltd \\
\hline & & ICICI Bank Limited & & & Nedbank Group Ltd \\
\hline & & IDBI Bank Ltd & & & Standard Bank of South Africa Ltd \\
\hline & & Indian Bank & Thailand & 9 & Bangkok Bank \\
\hline & & Indian Overseas Bank & & & Bank of Ayudhya \\
\hline & & Kotak Mahindra Bank & & & Kasikorn Bank \\
\hline & & Oriental Bank of Commerce & & & Kiatnakin Bank \\
\hline & & Punjab National Bank & & & Krung Thai Bank \\
\hline & & State Bank of India & & & Siam Commercial Bank \\
\hline & & Syndicate Bank & & & Thanachart Bank \\
\hline & & UCO Bank & & & Tisco Bank \\
\hline & & Union Bank of India & & & TMB Bank \\
\hline & & United Bank of India & Turkey & 7 & Akbank T.A.S. \\
\hline & & Vijaya Bank & & & Turkiye Garanti Bankasi A.S. \\
\hline & & & & & Turkiye Halk Bankasi A.S. \\
\hline & & & & & Turkiye Is Bankasi A.S. \\
\hline & & & & & Turkiye Vakiflar Bankasi TAO \\
\hline & & & & & Turkiye Ziraat Bankasi A.S. \\
\hline & & & & & Yapi ve Kredi Bankasi A.S. \\
\hline
\end{tabular}

Note: Global systemically important banks (G-SIBs), as of end-2014, are shown in bold. Banks that do not have equity-implied EDF measures are shown in italics. 